\title{
Tonsillar Lymphoma
}

National Cancer Institute

\section{Source}

National Cancer Institute. Tonsillar Lymphoma. NCI Thesaurus. Code C5918.

A primary lymphoma that affects the tonsil and the bulk of the tumor is in this anatomic area. The majority of cases are B-cell non-Hodgkin lymphomas. 